\title{
At the Crossroads: A Case Study of Humanism in High School English Education in China
}

\author{
YE Xiao-ya \\ Beijing Foreign Studies University, Beijing, China
}

\begin{abstract}
The concept of "equality" and the importance of "rational and critical thinking" are essential components of humanism. New English Curriculum for Chinese Primary Schools and Junior/Senior High Schools indicates English is not only a "Tool", but also carries information and features of "Humanism". This article conducted one year-long qualitative case study of three high school English teachers from different districts in Beijing. Data were collected through class observation, teachers' office observation, and interviews with teachers, students, and parents. Data analysis followed qualitative procedures. Findings show that the three English teachers do not have strong awareness of humanism: None of them believes students and teachers are equal. Two teachers incorporate "rational and critical thinking" when they work as head teachers, but neither applies it when they serve as English teachers. Humanistic education is not prevalent but effective in teachers' development training. More relevant trainings are expected to benefit more teachers.
\end{abstract}

Keywords: English teachers, humanism, equality, critical thinking

\section{Introduction}

Humanism emphasizes the value and agency of human beings, and it affirms the notion of "human nature". The concepts of equality as well as the importance of rational and critical thinking are essential components of humanism. Rousseau believes that all human beings are born to be equal, and he states,

Every man being born free and his own master, no one, under any pretext whatsoever, can make any man subject without his consent. To decide that the son of a slave is born a slave is to decide that he is not born a man. (Rousseau, 2003, p. 71)

That is to say no matter what social status an individual stays in, he is supposed to be equal to anyone else in the world and has the rights he deserves. As for critical thinking, Russell (1956, p. 131) believes that one central purpose of education is to prepare students to be able to form "a reasonable judgment on controversial questions in regard to which they are likely to have to act", and maintains that education needs to offer "training in judicial habits of thought". Many critical thinking theories address the problems of how to develop reasoning abilities and encourage students to be more rational (Paul, 1990; McPeck, 1981; Siegel, 1988). Glaser (1941) proposes that the ability to think critically involves three elements:

(1) An attitude of being disposed to consider in a thoughtful way the problems and subjects that come within the range of one's experiences;

YE Xiao-ya, Ph.D. candidate, School of English and International Studies, Beijing Foreign Studies University. 
(2) Knowledge of the methods of logical inquiry and reasoning;

(3) Some skill in applying those methods.

Rational and critical thinking need to be applied to basic education to cultivate students' mind. Dewey (1910) recognized that a curriculum aimed at building thinking skills would benefit the individual learner, the community, and the entire democracy.

Humanism in English education has been studied by scholars in many countries (Arnold, 1998; Kemp, 1994; Gadd, 1988; Stevick, 1984). However, this area has just received attention in K-12 education in China. New English Curriculum for Chinese Primary Schools and Junior/Senior High Schools (Ministry of Education of the PRC, 2012) indicates that English is not only a "Tool", but also carries information and features of "Humanism". This can be regarded as a breakthrough since Ministry of Education attaches equal importance to the "Tool" feature and "Humanism" feature of English education for the first time. However, the New English Curriculum for Chinese Primary Schools and Junior/Senior High Schools (2012) does not include definition, description or concrete explanation of "Humanism" feature in the field of English education. This may cause the problem that English teachers in high schools do not understand humanism, and therefore can hardly apply it to teaching practice. Although humanism places an important role in high school English education, this area is rarely studied in a Chinese context. The researcher intends to address this gap to occupy the niche in this article. Humanism is to be studied from two perspectives: (1) equal relationship between teachers and students and (2) rational and critical thinking.

The following research questions are to be answered:

(1) How do the three teachers interpret "humanism" in education?

(2) How do the three teachers understand "equality" and "rational and critical thinking" regarding humanism?

(3) Do the teachers receive any effective training concerning "humanism"? If so, what is it like?

\section{Methodology and Data Collection}

Chapelle and Duff (2003, p. 164) define the case study specifically for language teacher-researchers in the following terms, "In TESOL, a case typically refers to a person, either a learner or a teacher, or an entity, such as a school, a university, or a classroom... In language policy research, the case may be a country". In this article, a qualitative year-long multiple-case study (Duff, 2008) was carried out. This study was conducted in three high schools in Haidian District, Fengtai District, and Daxing District respectively in Beijing, China. The basic information of the three teachers is listed in the following Table 1.

Table 1

Specific Information of Three Teachers

\begin{tabular}{llllll}
\hline Name & Area of school & Age & Years of teaching & Teaching grade & Type of school \\
\hline John & Haidian District & $35-40$ & 11 & 9 & Key high school \\
Lucy & Fengtai District & $30-35$ & 8 & 9 & Non-key high school \\
Betty & Daxing District & $30-35$ & 9 & 10 & Non-key high school \\
\hline
\end{tabular}

Data was collected by observations and interviews. The first case study of John involved classroom observation, teachers' office observation, and interviews with a student and his parent; the second case study of Lucy and third case study of Betty involved classroom observation and interviews with the two English 
teachers respectively. Each participant was interviewed at least three times, following semi-structured guidelines (Merriam, 1998). Interviews lasted an average of 50 minutes, ranging from 45 to 65 minutes.

\section{Case Study}

\section{First Case Study of John}

Critical incidence from classroom observation and teachers' office observation. Tom was a Grade 9 student at a key high school in Haidian District, Beijing. This event took place in May 2015. Some girls in Tom's class had quite original and independent thoughts, so they set up a QQ (chat software) chat group and invited all students to join in. They mainly discussed their study, daily life, interests, etc. Around 40 students joined the chat group. They used the English teacher John (also served as the head teacher)'s nickname to call the group in order to make it sound funny. John applied to join the group, but was rejected by the students. However, he did not give up. One day Tom went to the office to ask John some questions, and John asked Tom for his user name and password of the QQ chat group, and intended to use Tom's information to log in. Tom thought it was wrong and immoral to do so, so he said he forgot the password and refused John's request indirectly. John said: "If you do not tell me, I will not answer your questions". Tom said: "That's OK. I will turn to other teachers for help". Then Tom left the office. Later David, a classmate of Tom, came to the office to ask John some questions, and John asked David for his user name and password. David released his personal information to John, and John logged onto the QQ chat group and checked all students' chat record. Meanwhile, Jason, another classmate of Tom, was in the office and observed what had happened. Later because of the information released from Jason, all students in the class knew David "betrayed" them, and called him as a "traitor". In order to protect David, John said to Tom in front of the whole class, "Thank you very much for your help. I can help you with your questions now". Tom considered it was immoral for John to say and do so. Thus he argued with John for a few words and left the classroom angrily. Tom was asked to write an apology letter to John; otherwise he would get a disciplinary punishment, which would be kept in his Student Record.

Interviews. John refused to be interviewed on this incidence, and therefore interviews were conducted with Tom and his mother.

(1) Interviews with Tom.

Tom expressed his feelings as following.

I thought John was rather immoral. How could he treat me like that? I found it hard to be in the class since my classmates might dislike me. Perhaps I was quite naive: I wanted to report this to the School's Administration. I believe the relationship between teachers and students is equal, and the School's Administration would judge it fairly. (Tom, interview, transcription, November 25, 2015)

The above data show Tom has a sense of justice and awareness of equality. He does not think students are inferior to teachers' authority, and he works hard to struggle for his equal right and defend for it.

(2) Interviews with Tom's mother.

Tom was from an above-middle class family. His parents were $45-50$ years old, both of whom got Master's Degree from prestigious universities in China, and served in administration positions in a National Corporation in China.

I was very angry hearing what happened. But when I felt calm, I thought the intention of the teacher might be good: Perhaps he wanted to know more about the students and made friends with them, but the way he treated students had serious problems. The extreme way John treated students made him distant from students rather than close to them. 
Students held negative opinions towards what John had done to them... I talked with John about this incidence, and when we talked about what he had done to my son after my son turned off his request, John said he was kidding at that time. However I thought at my son's age, Tom could hardly understand such adult's humor. At the end John admitted in order to protect David, he said to my son in front of all the other students "thank you for your help, and now I can answer your questions". I considered it was rather inappropriate for him to do so, especially to the students at my son's age. They did need recognition from the class: They needed a sense of belongings. What the teacher did made my son sound like a traitor of the class. So my son reacted a little bit extremely: argued with John, left the room and slammed the door. John ran after my son, and declared loudly if my son did not give him an apology letter the following day, my son did not need to go to school anymore. (Tom's mother, interview, transcription, November 4, 2015)

The above data show John does not have a basic equality concept. Firstly, as independent individuals, students have the right to set up a chat group to communicate. They have the right to speak. Secondly, user names and passwords are students' private information, and they have the right to keep their personal information in privacy. Thirdly, students have the right to refuse teacher's unreasonable or immoral requests without being threatened. Fourthly, when students are framed up by the teacher, they have the right to defend themselves in public and declare the truth.

Since this incidence took place at a special time: two months before the Senior High School Entrance Exam, the most competitive and decisive exam for Grade 9 students in China, it was more difficult for parents to deal with it.

The most pressure at that time was that my son was going to graduate, and I did not want him to be bothered, affected, and distracted by any affair. Thus I had no other way but to negotiate in between. I stood from the educator's perspective. I told my son John cared about students and wanted to make friends with them, but sometimes he did not know how to make it. Although the way John treated him had some flaws, I hope he could understand it... In addition I said we Chinese had the tradition to respect our teachers. Even though the teacher made some mistakes, as a student he should never slam the door and utter bad words to the teacher. He deserved any disciplinary punishment for what he had done to the teacher... I did criticize my son at that time from the teacher's perspective; however, honestly I disagreed with what the teacher had done. Perhaps if I were a mother in the West, I could tell my son he was right; however, I could not do that in China. (Tom's mother, interview, transcription, November 25, 2015)

I think making friends with students cannot happen out of teacher's authority; it can only take place due to students' willingness. Nowadays lots of teachers are test-oriented, and the role of teachers is administrator. As long as the teacher can administrate the class well, nothing wrong happens, and the school is not responsible for any accident, then the teacher is considered as a good teacher. However I think real education means to befriend students and know their internal ideas rather than peek their privacy. Teachers should not only teach students knowledge, but more importantly, teach students how to be moral individuals. (Tom's mother, interview, transcription, November 25, 2015)

The data above illustrate interpretation of this incidence from a parent's perspective. Firstly, Tom's mother handles this event rationally. Secondly, she thinks students' acceptance of a teacher should be out of their trust and willingness rather than out of the teacher's authority. The relationship between teachers and students is equal. Thirdly, the role of teachers is not "administrator", but "friend" of the students. Fourthly, teachers do not only instruct knowledge, but also teach students how to be moral people. These reflect the mother's belief of "equality", "rational thinking", and "morality" regarding humanism.

To sum up, in this case study the English teacher John does not have sense of "equality", and does not respect students' basic rights. Student Tom has a strong sense of justice and equality, and thinks students should struggle for their equal rights and protect their rights. Tom does not surrender to the authority of the teacher. Tom's mother basically agrees with his son's deeds, but she has no other choice: She thinks if she were 
in the West, she could support her son. However in China, she has to stand from teachers' perspective and criticizes her son in order to negotiate in between and resolve the confrontation.

\section{Second Case Study of Lucy}

Lucy is an English teacher at a below-average Junior High School in Fengtai District, Beijing. She has eight-year teaching experience and has served as a head teacher for six years.

Initially Lucy was inquired of her perception and understanding of humanism.

As for humanism, I think it is too broad, too intangible. I do not know what it means clearly. (Lucy, interview, transcription, December 6, 2015)

Then Lucy was informed that one important component of humanism was equality, and was asked whether she thought the relationship between teachers and students was equal.

Definitely NOT. One important duty for teachers is to maintain discipline in class in addition to teaching. However, nowadays students are not well-disciplined. As a teacher, if you do not put yourself in a superior position, the class will have no rule to obey and will turn to be chaotic. If students think they are equal to you, you cannot instruct them... The role of teachers is Guider. You need to guide your students to do this, to do that. (Lucy, interview, transcription, December 6, 2015)

The above data show Lucy believes the role of teachers is "guider". No matter whether she serves as an English teacher or a head teacher, the relationship between teachers and students is unequal; otherwise there is no way for teachers to conduct regular teaching and class management.

Lucy expressed her understanding regarding incorporation of "rational thinking" and "critical thinking" in her instruction.

Yes, I do incorporate. For example when I work as a head teacher, I find some students have the impulse to fight with other students. It is hard for them to control themselves. Thus I teach them how to manage their emotion and think rationally. I guide them to predict the consequences, and encourage them to jump out of their emotion and look at the issue objectively... Sometimes we discuss social news in class and invite students to talk about their opinions. Do you remember there was a "Fan Paopao", the teacher who ran away first and left his students behind when the earthquake took place? We discussed this topic in class: Whether "Fan Paopao" was right or wrong. Students in my class had different ideas and had a debate.

But as an English teacher, I rarely conduct rational thinking and critical thinking in my language instruction... English teaching in Junior High School is very basic. Even though New English Curriculum states that English education has both the "tool" feature and "humanism" feature, as long as High School Entrance Exam exists, only the tool feature matters. Perhaps in key schools teachers may incorporate humanistic spirit in class teaching, but as a teacher at a below-average school, we can hardly do that.

In the teachers' development training in Fengtai District, the instructor just read the content of "Humanism" feature in the New English Curriculum and interpreted it briefly, and that's it. We do not touch upon it anymore in the training. (Lucy, interview, transcription, December 6, 2015)

The above data indicate Lucy incorporates rational thinking and critical thinking in her work when she serves as a head teacher. She guides and assists students to perceive the world and solve problems rationally and critically. Nevertheless as an English teacher, she rarely incorporates rational thinking and critical thinking in class. She thinks even though the New English Curriculum emphasizes the importance of humanism in English education, there is no way for her to apply it to practice in her school. Since High School Entrance Exam only focuses on the "tool" feature, teachers rarely touch upon the "humanism" feature. When she talks about "humanism", she uses the word "indoctrinate", from which we can see indoctrination approach plays a 
significant role in teaching from Lucy's perspective. Furthermore, humanism is not included in Lucy's teachers' development training and there is no instruction on how to implement it in practice.

To sum up, Lucy has little knowledge of humanism. She thinks the role of teachers is "guider". No matter whether she works as a head teacher or as an English teacher, the relationship between teachers and students should not be equal. She rarely incorporates the "humanism" feature in her instruction. She does not receive any teachers' training regarding humanism and does not know how to implement it in practice.

\section{Third Case Study of Betty}

Betty is an English teacher at a Senior High School, which is an average school in Daxing District, Beijing. She has nine years teaching experience, and has served as a head teacher for four years.

Betty has a basic knowledge of humanism and states:

I incorporate it in some educational activities. For example some articles in our textbook can be related to humanism, or some essays in the reading exercises can be associated with humanism. However, I can hardly apply it every day.

When being inquired about the relationship between teachers and students, Betty expresses:

It CANNOT be equal. If it is equal, there is no way to rule or discipline the class, and students will not follow you. For instance students in our school are not well-disciplined, so when you set the deadline of homework, you have to be in a superior position; otherwise most students will not fulfill the task.

As an English teacher, it is hard to include critical and rational thinking in my class since our students are at a relevant lower level. However, as the head teacher, yes. For instance a few students in our school sometimes fight with each other because of trivial issues. Thus as the head teacher I need to teach them to think rationally; otherwise they will get disciplinary punishment from the school.

We had a training regarding humanistic education in Daxing District last year. Teachers from different disciplines participated in this training. We were required to watch videos, reflect on them, write comments, etc. Prior that training I rarely paid attention to humanistic education, and I was more test-oriented. However, after I took part in that training, I realized the meaning of humanistic education and tried to apply it to my daily work. Consequently, I can see the change in my students. For example, one student in my class lived with his grand-parents and I had no information about his own parents. He was quite arrogant, did not like to speak with others and stayed alienated from his classmates. One time I organized all students to celebrate his birthday in class, and we wanted him to know that we did care about him and love him by doing this. He was deeply moved. After that he changed: he began to be able to accept his classmates and teachers, could communicate with others and was not that arrogant anymore. (Betty, interview, transcription, October 15, 2015)

To sum up, Betty does not think the relationship between teachers and students can be equal. She has received some basic training regarding humanistic education and finds it quite beneficial. Thanks to the training she makes change in her teaching: she is not that test-oriented anymore, makes effort to apply what she has learnt to practice, and has witnessed positive changes in her students.

\section{Conclusion}

The three English teachers in this study do not have a strong awareness of humanism. Even though the parent and the student in this study do not think teachers are authoritative and superior, none of the three teachers believes students and teachers are equal. Two of them apply "rational and critical thinking" in their education when they work as head teachers, but none of them is able to apply it when they only serve as English teachers. Humanistic education is not prevalent in teachers' development training, and only one teacher in this study has received it. The result of the training is quite positive. Therefore, more trainings regarding humanistic education are expected to benefit more teachers. 
The major contribution made by this study lies in the description of understanding and application of humanism in English education in China. Findings may arouse attention on this issue, promote English teachers' professional development, and benefit English learners in China in the long run. The results of this study may not be only limited in Beijing. More studies are needed in other provinces in China and in other developing countries in order to present a more holistic image of humanism in English education.

\section{References}

Arnold, J. (1998). Towards more humanistic English teaching. ELT Journal, 52(3), 235-242.

Chapelle, C., \& Duff, P. (2003). Some guidelines for conducting quantitative and qualitative research. TESOL Quarterly, 37(1), 163-168.

Dewey, J. (1910). How we think. Michigan: University of Michigan Library.

Duff, P. A. (2008). Case study research in applied linguistics. New York, NY: Lawrence Erlbaum.

Gadd, N. (1998). Towards less humanistic English teaching. ELT Journal, 52(3), 223-234.

Glaser, E. M. (1941). An experiment in the development of critical thinking. New York: Bureau of Publications, Teachers College, Columbia University.

Kemp, J. B. (1994). Arousing the sixth emphasis within humanism in English language teaching. ELT Journal, 48(3), $243-252$.

McPeck, J. (1981). Critical thinking and education. New York: St. Martin's Press.

Merriam, S. B. (1998). Qualitative research and case study applications in education. San Francisco, CA: Jossey-Bass.

Ministry of Education of the PRC. (2012). New English curriculum for Chinese primary schools and junior/senior high schools. Beijing: Beijing Normal University Press.

Paul, R. (1990). Critical thinking: What every person needs in a rapidly changing world. California: Sonoma State University.

Rousseau, J. (2003). The social contract. New York: Dover Publications.

Russell, B. (1956). Portraits from memory and other essays. London: George Allen and Unwin.

Siegel, H. (1988). Education reason. New York: Routledge.

Stevick, E. (1984). Talking shop: Earl Stevick on humanism and harmony in language teaching. ELT Journal, 38(2), 103-107. 